\title{
O lado oculto do lusotropicalismo: o legado de Gerald Bender na literatura e pensamento angolanos
}

\author{
Filipe Abraão Martins do Couto \\ Universidade Nacional de Timor-Lorosa'e
}

\begin{abstract}
Resumo
Pretende-se neste artigo desenvolver a perspectiva de Gerald Bender em relação ao lado oculto da ideologia lusotropicalista em Angola. Para compreender esta posição, torna-se necessário fazer uma incursão através de alguns episódios fundamentais da história de Angola para se apurar quem foram os protagonistas da missão divina de Portugal em Angola e se a colonização portuguesa se constituiu ou não como uma colonização mais fraternal em comparação com outras colonizações europeias. Depois de circunscrever como se desenvolveu a interpenetração cultural em Angola, procurar-se-á determinar o impacto e importância do legado de Gerald Bender na literatura e pensamento angolanos.
\end{abstract}

Palavras-chave: Gerald Bender; missão divina; lusotropicalismo em Angola; pensamento angolano.

\begin{abstract}
The aim of this article is to develop Gerald Bender's perspective on the hidden side of the lusotropicalist ideology in Angola. To understand this position, it is necessary to make a foray through some fundamental episodes in the history of Angola to determine who were the protagonists of Portugal's divine mission in Angola and whether or not Portuguese colonization was constituted as a more fraternal colonization compared to other European colonizations. After circumscribing how cultural interpenetration in Angola developed, an attempt will be made to determine the impact and importance of Gerald Bender's legacy in Angolan literature and thought.
\end{abstract}

Keywords: Gerald Bender; divine mission; lusotropicalism in Angola; Angolan thinking.

Recebido em: 10/02/2020

Aprovado em: 22/07/2020

\section{Introdução: uma perspectiva histórica e cultural de Angola}

A investigação levada a cabo por Gerald Bender (2013) constitui, para muitos investigadores angolanos, um estudo incontornável em relação ao papel do lusotropicalismo em Angola, desde o final do século XV até ao século XX. Nessa obra, está presente um exame 
crítico ao ideário lusotropicalista ${ }^{1}$ ao longo da história colonial, considerada em termos políticos, estratégicos e sociais.

No decorrer deste período, os defensores do lusotropicalismo advogavam (e muitos ainda advogam), com efeito, a ausência total do racismo entre portugueses e colonizados, tendo em conta a própria história da interação humana entre portugueses e os povos tropicais, caracterizada pela solidariedade e igualdade entre os homens, sendo que a prova infalível desta solidariedade e igualdade seria o mulato, que surge enquanto produto de uma suposta união antirracista.

Se para muitos a ideologia lusotropicalista constitui uma "interação humana racialmente igualitária", Gerald Bender contesta este argumento, e defende que o lusotropicalismo jamais fora sinônimo de igualitarismo e solidariedade entre homens de diferentes culturas. Para Bender, interação ou interpenetração biológica não significa o mesmo que igualdade ou solidariedade entre homens de diferentes raças (2013, p. 49).

O estudo começa por apontar a propaganda heroica em torno dos feitos gloriosos dos portugueses, levada a cabo por vários exploradores, escritores e intelectuais, que se iniciou no século XV e se estendeu até ao século XX. Durante esse período, a "intelectualidade portuguesa", a "literatura" e o "discurso político" sempre enalteceram a bravura dos soldados e exploradores, a grande capacidade plástica dos colonos e, sobretudo, "a responsabilidade divinamente inspirada de Portugal de transmitir os valores cristãos e civilização ocidental aos indígenas de África, das Américas, da Índia e da Ásia” (2013, p. 30).

Esta responsabilidade divinamente inspirada de Portugal tinha como característica a sobreposição das "virtudes humanas e espirituais" em relação às "virtudes materiais do colonialismo português", que seriam, neste caso, as grandes responsáveis por "gerarem sociedades multirraciais harmônicas em Angola, Moçambique e Guiné” (2013, p. 30). Ressaltese que esta missão colonizadora espiritual e humana - traduzida numa missão divina do segundo povo eleito por Deus, os portugueses - foi quase sempre o motivo da colonização portuguesa, pelo menos, num sentido literário e mítico.

É sobretudo a partir do Estado Novo de Salazar que se vai exaltar este discurso histórico dos feitos gloriosos de Portugal e dos portugueses, que iria servir, fundamentalmente, para inspirar o orgulho dos lusitanos. Como refere Bender, "esta glorificação da missão colonizadora servia principalmente as necessidades psicológicas, mais do que as necessidades políticas, dos sucessivos regimes portugueses" (2013, p. 30). Simultaneamente, o dogma da missão colonizadora de Portugal servia também de escudo e proteção contra os ataques

O lusotropicalismo é uma teoria formulada por Gilberto Freyre que preconiza uma aptidão especial dos portugueses em adaptarem-se a ambientes adversos e tropicais, que se singulariza por uma capacidade de inter-relação e interpenetração cultural e biológica, caracterizada pela ausência de preconceitos rácicos e pelo tratamento igualitário em relação a outros povos e etnias. 
anticolonialistas que proliferavam da Europa. O Brasil era o paradigma perfeito de uma sociedade multirracial harmônica, criada pelos portugueses, estatuindo-se, para o panorama internacional, como a prova incontestável de que seria possível para os portugueses criar sociedades multirraciais harmônicas em África e na Ásia. ${ }^{2}$ Nesse cenário, como explica Bender, "o Brasil não só forneceu a Portugal a evidência para uma argumentação de 'inocência por associação', como também a ideologia do lusotropicalismo explicava as atitudes portuguesas quanto às relações de raça". ${ }^{3}$ Neste caso, o lusotropicalismo seria sinônimo de tolerância racial, de solidariedade e de igualdade entre os homens. Seria possível, com base no ideário lusotropicalista, fazer de Angola um novo Brasil, daí a necessidade da colonização, que seria sinônimo de civilização.

Se, por um lado, Portugal conseguia convencer o "mundo" da validade das suas premissas lusotropicalistas, por outro lado, um "número importante de angolanos pretos, mestiços e brancos condenaram o lusotropicalismo como um mito cruel perpetrado para cegar o mundo às realidades de opressão e exploração racial" (2013, p. 36). Criticaram o lusotropicalismo por insistir demasiado nas "ligações sexuais", enquanto se ignoravam profundamente as questões econômicas e políticas do povo angolano, bem como o trabalho forçado a que o africano era sujeito diariamente, a expropriação de terras, as torturas físicas e psicológicas e os massacres de "aldeias inteiras". A tudo isto, avaliaram os efeitos das políticas de assimilação portuguesas, consideradas quase nulas, ${ }^{4}$ bem como o acesso dos africanos à educação e à política, quase inexistente. Tais africanos angolanos questionavam se estes fatos poderiam conciliar-se "com a pretensão de Portugal ao sucesso da sua missão civilizadora" (2013, p. 37).

Neste enquadramento, é possível considerar duas perspectivas antagônicas que se foram desenvolvendo ao longo da história e culminaram na época do Estado Novo: a primeira, de Portugal e para muitos portugueses, a noção de que o lusotropicalismo se constituía como

2 "Com o início da intensificação da crítica anticolonialista, nas Nações Unidas, em 1951, Portugal principiou deslocar a ênfase da sua 'missão' de exaltação do colono ultramarino para o engrandecimento das sociedades multirraciais que estava a emergir em Angola e Moçambique. Doravante, a qualidade da sua política racial em África constituiria a primeira linha da sua defesa de Portugal contra a crítica internacional. Além disso o termo legal 'colónia' foi abandonado em favor de 'Províncias Ultramarinas' — que possibilitou António de Oliveira Salazar rejeitar ressentidamente a crítica estrangeira como interferência injustificável nos negócios internos do seu país" (BENDER, 2013, p. 31).

3 Mesmo W. E. B. Du Bois considerou, logo após a sua visita a Lisboa, no Terceiro Congresso Pan-Africanista, que não existia menosprezo, antipatias nem ódios entre portugueses e africanos (BENDER, 2013, p. 34).

4 Antes de 1961, “menos de um por cento dos africanos em Angola eram considerados 'civilizados' ou 'assimilados"' (BENDER, 2013, p. 37). 
sinônimo de igualitarismo e solidariedade racial; 5 a segunda, para alguns angolanos (os poucos que tinham voz), foi desenvolvida uma noção de que o lusotropicalismo se efetivava como um mito, "que ignorava as realidades da arrogância racial, genocídio cultural, degradação humana e exploração" (2013, p. 38).

É importante também salientar que as bases de uma "missão civilizadora" em terras africanas - sejam elas de índole religiosa, política ou econômica, só seriam concretizadas na medida em que se acreditasse na superioridade da própria missão. Neste sentido, se o objetivo era civilizar o outro, então a crença subjacente a esta missão é que aquele que vai ser objeto da colonização é inferior, a sua cultura é inferior, as suas línguas são inferiores, ou seja, o outroafricano é inferior, em todas as dimensões. É com base neste argumento que Bender não terá dúvidas em afirmar que "Portugal caracterizou os africanos como intrinsecamente inferiores; de facto, a autoadulação de Portugal acerca da sua 'missão civilizadora' dependia de semelhante inferioridade" (2013, p. 56). Por outras palavras, a interação rácica e as relações sexuais não são sinônimas de igualitarismo e de solidariedade entre brancos e negros. A máxima preconizada de que "Deus criou o homem e os portugueses criaram o mestiço" (2013, p. 34) não pressupõe uma interação de cariz solidário, de liberdade e de igualdade fraternal. Esta observação é um dos pontos fundamentais na análise de Bender: "supor que a prontidão dos portugueses e de outros europeus para se unirem às mulheres não brancas era sinal de atitudes igualitárias europeias, mais do que de sensualidade, constitui uma grande distorção da realidade" (2013, p. 99).

O conceito de lusotropicalismo funcionou apenas como uma armadura, que servia para proteger os portugueses das críticas internacionais de que eram alvo, ao mesmo tempo que lhes permitia atuar em terras africanas com toda a liberdade e "libertinagem". É perfeitamente possível existir interação rácica e relações sexuais sem igualdade nem solidariedade, sobretudo quando prevalece a crença da superioridade de uma cultura sobre outra, ou a ideia de transformar africanos em "portugueses".

Numa primeira conclusão, tal como refere Bender, não é possível prevalecer uma "harmonia racial numa sociedade multirracial em que os indivíduos duma raça se consideram a si mesmos superiores, porque querem inevitavelmente tentar dominar aqueles que julgam inferiores" (2013, p. 365). Esta afirmação é a principal refutação da teoria lusotropicalista. Ao prevalecer o etnocentrismo cultural, não há lugar para um encontro entre iguais e muito menos

\footnotetext{
5 É importante explicar esta posição. Para Bender, "para a maior parte dos não-portugueses, o lusotropicalismo é (quando muito) um mito romântico ou (no pior dos casos) uma mentira odiosa para obscurecer as realidades do colonialismo português. Os estrangeiros raramente admitem que o povo português tenha realmente acreditado no lusotropicalismo ou que este inspirasse a política e a ação portuguesas em África. No entanto, para a esmagadora maioria do povo português, anteriormente ao golpe militar de abril de 1974, o lusotropicalismo representou verdadeiramente a política, a prática e os objetivos portugueses. É duvidoso ter havido outra ideologia que mais ampla e fervorosamente fosse aceite pelos portugueses ou tenha dado azo a tanta atenção escrita, dentro de Portugal" (2013, p. 56).
} 
o respeito para com outras culturas. À luz da filosofia lusotropicalista, quando os portugueses se consideram superiores - em todos os aspetos - aos angolanos, predomina nesta relação o racismo e a xenofobia.

O mesmo se passa quando se aborda o tema da tolerância racial que se encontra ligado às raízes lusotropicais. Quando se fala das atitudes tolerantes dos portugueses em relação aos angolanos, tais não se devem confundir, na percepção de Bender, "com o respeito pelas culturas e povos africanos. Pelo contrário, o paternalismo português baseava-se na arrogância cultural e conotava um profundo desrespeito pelas culturas e povos africanos" (2013, p. 358). Estas atitudes de arrogância cultural e de desrespeito profundo “constituíam o cerne da 'missão civilizadora' e do sistema do indigenato que visava elevar os africanos de uma existência considerada atrasada e inferior para o nível supostamente superior da civilização portuguesa" (2013, p. 368). Numa palavra, não se pode confundir lusotropicalismo com igualdade rácica, nem paternalismo ou tolerância com respeito pelo outro-africano e pelas suas culturas.

\section{Os protagonistas da missão divina de Portugal em Angola}

Segundo Bender, é através da história que é possível averiguar a autenticidade das intenções de Portugal em relação à sua missão civilizadora. Com efeito, o autor considera que é a partir do século XV que se constrói a concepção lusitana "de que os africanos beneficiavam da subjugação branca por causa da oportunidade de contratarem com uma civilização superior" (2013, p. 258). Esta concepção portuguesa predominou até ao Estado Novo, ${ }^{6}$ numa altura em que também proliferava na Europa ideias que sustentavam o africano como sendo de natureza sub-humana, um homem selvagem ou da idade do ferro.

No entanto, este contrato com uma civilização superior ao longo dos séculos não beneficiou os angolanos. Com efeito, a história dos portugueses em Angola, até ao século XX, na leitura de Bender, "é essencialmente a história dos criminosos exilados — degradados, que eram descarregados nas costas de Angola como lixo, já que assim eram considerados". ${ }^{7} \mathrm{O}$ autor faz uma análise histórica minuciosa do processo de colonização portuguesa em Angola, estimando que, entre a chegada de Diogo Cão ${ }^{8}$ a terras angolanas até ao século XX, "a esmagadora maioria dos portugueses em Angola eram condenados exilados ou degredados" (2013, p. 133).

Tendo em consideração todas as adversidades físicas, geográficas e pandêmicas que representava Angola, o autor apresenta provas físicas que sustentam que desde sempre foi uma

\footnotetext{
6 Pelo menos, as três primeiras décadas do Estado Novo.

7 Bender fornece provas escritas que comprovam que "Portugal foi a primeira nação europeia a enviar a escória das masmorras e prisões metropolitanas para o exílio nas colónias ultramarinas, já desde princípio do século XV, muito antes de Diogo Cão ter chegado a Angola. Portugal foi igualmente o último a aperceber-se da destrutividade e do perigo de semelhante política e, por fim, a aboli-la” (2013, p. 129).

8 Em 1484
} 
missão extremamente penosa para os sucessivos governos de Portugal, ao longo de quinhentos anos de colonização, persuadir homens livres portugueses a participarem das missões de expedição e colonização em Angola. Como tal, tendo em conta a escassez de recursos humanos e os limitadíssimos recursos materiais e financeiros, o processo de povoamento do litoral e do interior angolano foi levado a cabo pela escória da sociedade portuguesa, os indesejados que permaneciam nas masmorras de Portugal.

Bender fornece diversos testemunhos do tipo de criminosos que foram descarregados na costa angolana ao longo dos séculos de colonização portuguesa. Ao contrário do que ocorreu com as estratégias de colonização na Austrália e, mais tarde, nos Estados Unidos da América, em que os processos de povoamento foram levados a cabo por degredados condenados por crimes ligeiros, as políticas portuguesas de povoação nos trópicos sempre se basearam num triplo critério: o primeiro baseava-se na premissa de que seria necessário verem-se livres da escumalha da metrópole; o segundo, dado o número muito reduzido de portugueses livres que emigravam para Angola, prevalecia a crença ingênua de que seria melhor povoar Angola com condenados brancos do que somente manter a reduzidíssima presença de portugueses livres neste país (cuja maioria eram soldados e missionários); o terceiro critério tinha como princípio o facto de se considerar, de forma unânime e ingênua, que Angola constituiria um novo país onde os criminosos poderiam começar uma nova vida - na agricultura, na pesca, na administração civil, entre outras áreas - , e que poderiam aproveitar esta oportunidade para se regenerarem, dando assim continuidade à "missão civilizacional" de Portugal, que tinha como objetivo transformar os africanos rudes e selvagens em africanos civilizados, de acordo com os padrões civilizacionais portugueses.

Contudo, só muito mais tarde (em pleno século XX) é que o governo de Lisboa se apercebeu das implicações destas políticas de povoamento. Os degradados mobilizados por Portugal eram assassinos, incendiários, violadores e pervertidos que, desde sempre, revelaram uma profunda aversão pelo trabalho, pela agricultura, pelo serviço militar, pela ordem e disciplina. Por outras palavras, como refere Bender, "as transgressões dos degredados em Angola não se limitavam ao roubo e à vigarice; eram condenados por quase todos os crimes imagináveis na colônia, desde o assassínio e a burla até à violação de raparigas órfãs" (2013, p. 159). É claro que este tipo de degredados facínoras, ao longo dos séculos, revelaram-se "parasitas dispendiosos" não só para o governo português, como também para a administração colonial, incapaz de os controlar, bem assim, acima de tudo, representavam uma ameaça séria para os africanos locais.

Assim, a história da colonização portuguesa em Angola, segundo Bender, é resumida com a história dos degredados portugueses ao longo dos séculos. No primeiro século, os degredados foram incluídos nas forças de expedição ao interior de Angola, registradas com inúmeras deserções e mortes; no século XVII, os degredados apropriaram-se de todas as 
posições nas forças de segurança, como a polícia e o exército, serviços e comércio, ${ }^{9}$ com todas as implicações para os nativos, bem como foram eles que desferiram o ataque à rainha Ginga, nas Pedras Negras; no século XVII e XVIII, os degredados "derrubaram o governo e saquearam Luanda"; no século XIX, os degredados alocados ao interior do país "pilhavam e dependiam dos africanos locais para a sua sobrevivência”; ao longo desses séculos, raramente trabalhavam, apenas expropriavam e violavam, fazendo do tráfico de escravos a sua principal fonte de receitas; no século XX, desalojaram agricultores africanos das suas terras, bem como de outras ocupações ${ }^{10}$ essenciais. Como é obvio, estes "esquemas de povoamento e colonização revelaram-se totalmente contraproducentes em relação aos objetivos traçados pelos teóricos coloniais de gabinete" (BENDER, 2013, p. 174).

Os lusotropicalistas, embora tenham glorificado "as virtudes do camponês português pobre e analfabeto em Angola", como sendo o "baluarte do povoamento branco em Angola", tendo em conta a premissa de que "quanto mais próximos os europeus e os africanos estivessem uns dos outros ao nível cultural (habitualmente interpretado como classe), mais amistosas seriam as relações entre as raças" (BENDER, 2013, p. 392). O que se passou, no entanto, foi precisamente o oposto: não só o governo português não conseguiu fazer dos degradados agricultores trabalhadores humildes para laborar em parceria "paternal" com as populações locais, como foi esta a "fina flor da colonização portuguesa" que cometeu as maiores atrocidades para com os angolanos. Por outras palavras, a missão divinamente inspirada de Portugal foi materializada, em Angola e ao longo dos séculos, pela escória da sociedade portuguesa, por facínoras e violadores que sempre procuraram os meios mais fáceis para subsistirem, pela pilhagem, tráfico de seres humanos e animais, expropriação de terras, corrupção nos serviços públicos e privados, entre outros.

É claro que foram as populações locais a pagarem o preço por este contrato civilizacional. Como é evidente, esta política de colonização teve implicações no âmbito social, cultural e educacional dos africanos. Os degredados nunca ou raramente serviram de intermediários

9 Como, por exemplo, o “comércio de bebidas alcoólicas por grosso e a retalho" (2013, p. 134).

10 É interessante constatar o que muitos soldados e governadores portugueses diziam em relação à constante vaga de degredados que aportavam em Luanda. O governador Sousa Coutinho, em 1866, dizia: “[Devemos] proibir de uma vez para sempre as penas que sobrecarregam este reino com prostitutas e degredados da pior espécie, [porque] a experiência de mais de dois séculos mostra que tais embarques foram inúteis e muitas vezes perigosos; [...] os seus vícios ganham raízes, gostam da ociosidade, estragam a sua saúde e morrem depressa e através deste excesso da adversidade as suas mortes tornam-se mais úteis que as suas vidas" (BENDER, 2013, p. 185-186). Heli Chatelein, linguista Suíço, em 1891, escreveu o seguinte: "Cada barco português continua a trazer cerca de cinquenta a sessenta emigrantes enviados para a costa ocidental pelo governo português afim de esvaziar as prisões e se ver livre de vagabundos perigosos e famélicos. Enquanto que a colonização racional seria uma bênção para a província e para a metrópole, este tipo de emigração assistida é uma maldição e uma fonte de perturbação sem fim” (BENDER, 2013, p. 131). Quirino Avelino de Jesus também referiu: “À medida que se ia tirando a nossa África da condição de mercado de escravos, transformamo-la num recetáculo de degredados. Da emigração livre não falamos, porque era diminutíssima e insignificante” (BENDER, 2013, p. 127). 
entre os africanos, a não ser para os caçarem e venderem como animais, ou para os obrigar a trabalhar como escravos para a subsistência dos mestres, ou para os expulsarem e lhes extorquir as terras agrícolas para seu benefício. Tal foi a violência física e psicológica, a marginalização e a exclusão do povo angolano; foram estes os principais valores legados pela missão civilizadora de Portugal em Angola, ao longo de cinco séculos.

\section{A colonização portuguesa em Angola: uma colonização fraternal?}

Renato Epifânio recorda-nos, por outro lado, que não se pode comparar a colonização portuguesa com outras colonizações europeias. Na sua percepção, a colonização portuguesa foi mais fraternal e solidária do que as outras colonizações europeias; caso contrário, não se compreenderia, tal como refere, "de todo as (singulares) relações de efetividade que existem [atualmente] entre os povos lusófonos" (EPIFÂNIO, 2017, p. 106).

Este argumento é discutível, por duas razões: a primeira, porque éuma premissa essencialista que não toma em consideração a realidade política e cultural de cada país que faz parte da CPLP (Comunidade dos Países de Língua Portuguesa): no caso de Angola, por exemplo, como é de conhecimento público, as "relações de efetividade" com Portugal têm conhecido ora avanços, ora recuos político-diplomáticos vários, diagnosticando-se uma complexidade ímpar em relação a qualquer desenvolvimento de plataformas de entendimento mútuo; a segunda razão prende-se com o fato de o argumento revelar também o desconhecimento da história e do pensamento africano, uma vez que também outros países africanos outrora colonizados mantiveram (e ainda mantêm) relações bilaterais privilegiadas com os ex-colonos, que se concretizaram imediatamente a seguir às suas independências políticas, ao contrário de Portugal. $\mathrm{O}$ caso do Senegal, presidido por Léopold Sénghor, constituiu um notável exemplo de uma filosofia político-ideológica orientada para superar a negação da cultura negra em relação ao outro, sobretudo o outro-colono ou o outro-europeu, logo após a descolonização, através da criação de uma civilização do universal (união entre brancos europeus com negros africanos) que vislumbrava a francofonia como uma das ferramentas para atingir esse fim (SÉNGHOR, 1977, p. 12).

O que se pretende argumentar é que não só as relações de afetividade entre Portugal e outros países de expressão portuguesa não são totalmente verdadeiras, porque, em primeiro lugar, estas relações de afetividade não contemplam todos os países que compõem a CPLP, como também, em segundo lugar, há casos de outros países ex-colonizados que não falam a língua portuguesa e mantêm relações de afetividade singulares com os ex-colonos. O Senegal é só um exemplo.

No que concerne à escravatura em Angola, Renato Epifânio recorda-nos que antes da chegada dos portugueses, Angola não era um paraíso, uma vez que já "havia racismo e escravatura entre os africanos quando os portugueses lá chegaram”. Assim, "o racismo e a escravatura não foram um exclusivo europeu, muito menos português” (EPIFÂNIO, 2017, p. 106). 
Este argumento surge na sequência de uma correção à pré-publicação da obra Racismo em português: o lado esquecido do colonialismo, editado numa parceria entre o jornal Público, Fundação Francisco Manuel dos Santos e Tinta-da-China, da autoria de Joana Gorjão Henriques, em que afirma que os portugueses deram "início à prática de tráfico de seres humanos no século XV, prática que só seria abolida quatro séculos depois” (HENRIQUES, 2016). Não se pretende de maneira alguma refutar a afirmação de Renato Epifânio a propósito do pioneirismo africano em relação à escravatura, mas o facto de ter existido escravatura entre os africanos antes da ocupação colonial portuguesa não iliba o comportamento dos portugueses em relação a esta prática que se concretizou posteriormente, sobretudo quando os portugueses internacionalizaram a escravatura a uma escala nunca antes vista. Segundo Joana Henriques, "só Angola, aliada ao Congo, representou quase quarenta por cento do mercado de escravos a nível mundial" (HENRIQUES, 2016). Estes números comprovam a importância que se deu à escravatura em Angola, bem como atesta a teoria de Bender em relação à farsa lusotropicalista que imperou em Angola durante cinco longos séculos.

\section{A interpenetração cultural em Angola}

Durante a ocupação colonial portuguesa em Angola, segundo Bender, a interpenetração cultural raramente funcionou. As atitudes etnocêntricas dos portugueses, entre os quais os degredados, consideravam as culturas tradicionais e línguas africanas como inferiores e primitivas. Como já foi referido, a paternalização de muitos portugueses também não significava respeito pelo outro-africano.

Por outro lado, não se pode afirmar que os portugueses, sobretudo os degredados, levaram a cabo uma política de integração social dos africanos na cultura portuguesa e nos costumes portugueses. Aliás, os comportamentos e atitudes dos degredados permitiram a muitos angolanos vislumbrar o tipo de civilização que não gostariam de ter. Tendo em consideração as políticas de povoamento branco levadas a cabo em Angola, sobretudo, por portugueses degradados - cuja execução foi oposta à teoria lusotropicalista, o que prevaleceu na prática foi a exclusão de grande parte dos angolanos da cultura e dos costumes portugueses.

Segundo Bender, o processo de assimilação elaborado pelos portugueses devia ocorrer em três fases distintas: a primeira fase, "a destruição das sociedades tradicionais"; a segunda, a "inculcação da cultura portuguesa"; por fim, "a integração dos africanos 'destribalizados' e 'lusitanizados' na sociedade portuguesa" (2013, p. 384). Segundo Bender, Portugal, ao longo de cinco séculos, nunca conseguiu concluir sequer a primeira fase do processo de assimilação, uma vez "que os portugueses foram incapazes de subverter os fundamentos das sociedades africanas". Da mesma forma, a segunda fase nunca passou de uma ilusão, uma vez que faltou "capacidade" e "determinação" para inculcar nos africanos a cultura portuguesa, que seria o coração da "missão civilizadora". A marginalização massiva dos angolanos em todos os setores 
dos serviços públicos e privados do seu próprio país, a ausência de estatutos sociais, a segregação política e educacional, as perseguições, castigos, violações, pilhagens e massacres, tiveram como consequência que grande parte dos africanos permanecessem "psicologicamente, se não no plano físico, fora do âmbito da cultura portuguesa". ${ }^{11}$ Por outras palavras, "a esmagadora maioria dos africanos tinha tão pouca familiaridade com a cultura portuguesa que a decisão para a assimilar nunca surgiu" (BENDER, 2013, p. 384).

Neste sentido, Bender defende que o sistema colonial português dominou por completo "os africanos sem jamais os ter integrado plenamente no sistema". A colonização portuguesa em Angola não conseguiu "absorver" os africanos, e por isso mesmo não se conseguiu levar a cabo a missão divinamente inspirada por Portugal. Tendo em conta a história da colonização em Angola, não "espanta que tão poucos africanos fossem considerados assimilados antes da independência" (BENDER, 2013, p. 390). ${ }^{12}$

O lusotropicalismo foi uma quimera em Angola, comprovada não só pela atitude etnocêntrica dos portugueses em relação aos africanos - como também pelos atos que foram praticados pelos portugueses durante séculos, que nunca demonstraram interesse pela interculturalidade, nem nunca promoveram estratégias que promovessem a igualdade e a solidariedade entre os homens, muito menos a sua intelectualidade, elevação educativa ou moral. ${ }^{13}$

11 "Por vezes, até os africanos que se casavam com portugueses pareciam ser impenetráveis às influências culturais portuguesas, da mesma maneira que os últimos o eram às influências africanas” (BENDER, 2013, p. 381).

12 “A principal razão para o reduzido número de assimilados em Angola nos meados do século XX é que poucos africanos tinham acesso às instituições que lhes poderiam transmitir a civilização portuguesa. De facto, Angola quase não possuía instituições que pudessem contribuir para a 'civilização' dos africanos" (BENDER, 2013, p. 273). As políticas educativas levadas a cabo pelos sucessivos governos de Portugal constituem exemplos da discriminação em relação ao acesso dos africanos à educação. No século XX, esta discriminação foi demasiado evidente: "A baixa prioridade que se concedia à educação salta imediatamente aos olhos, quando se compara o número de estudantes de Angola com os de outras antigas colónias europeias: em 1952, por exemplo, Angola tinha 14898 alunos no ensino primário (mais de dois terços eram brancos) em comparação com as populações de alunos africanos nesse mesmo ano de 418898 no Ghana e 943494 no Zaire (antigo Congo Belga). Portugal não procurou rivalizar com as políticas coloniais belgas, francesa e inglesa e inculcar a sua cultura através da educação formal. $\mathrm{O}$ agente português de civilização não era o professor primário formal, mas o 'informal' (e, muitas vezes, menos instruído) patrão português" (BENDER, 2013, p. 274).

13 Joana Gorjão Henriques também defende que não se pode perpetuar uma narrativa de um colonizador que não discriminava apenas porque se miscigenou com as populações locais. "[...] E coloco ainda mais umas perguntas: porque não nos é ensinado na escola que existiu um apartheid em Angola e em Moçambique, alimentado por Portugal? Porque insistimos num olhar benevolente sobre um Portugal que não hesitou em promover o trabalho escravo até 1974? Vamos perpetuar a narrativa de um colonizador que não discriminava porque se miscigenou com as populações locais, quando sabemos que obrigava essas pessoas a despirem-se da sua identidade africana, a mudar de nome, a alisar o cabelo ou a esconder a sua língua? Até quando iremos contribuir para uma mentalidade acrítica sobre um dos fenómenos mais violentos da nossa história? Finalmente: o que diz esta perspetiva de brandura de olhar sobre nós próprios, portugueses?” (HENRIQUES, 2016). 


\section{Importância da obra de Gerald Bender na literatura e pensamento angolanos}

O estudo de Gerald Bender influenciou e continua a influenciar uma nova geração de artistas, escritores, acadêmicos e pensadores angolanos, entre os quais se destacam Raúl Tati, José Manuel Imbamba, Muanamosi Matumona, António Filipe Augusto, entre outros, que conseguiram levar mais longe a reflexão sobre a interpretação da história angolana e africana sob a influência do lusotropicalismo. ${ }^{14}$

A análise e interpretação da ideologia lusotropicalista tem-se constituído, nos últimos anos, um dos temas nucleares na literatura e pensamento angolanos. A compreensão dos seus princípios, finalidades e práxis raramente aparece divorciada de muitos males que assolam as culturas angolanas na contemporaneidade.

Na leitura do filósofo angolano José Manuel Imbamba, os portugueses estão ligados a dois marcos históricos - de três, no total — que contribuíram para a decadência cultural angolana e para a crise do muntu: ${ }^{15}$ o primeiro marco histórico está associado aos contatos com os portugueses, em que "a sociedade angolana viveu sempre num clima de violência, guerras, ganâncias, perseguições, traições" (IMBAMBA, 2010, p. 108). Mediante a "instituição do comércio de escravos", refere Imbamba, "nasceu, consequentemente, uma sociedade escravocrata", um país, portanto, de "guerra e de comércio", de "quinhões e de despojos" pessoais, um país sem escrúpulos e sem lei, com sérias repercussões físicas e mentais no povo angolano.

Segundo, uma vez abolida a escravatura formal, mas com a colonização assumida por parte de Portugal, "as tensões sociais subiram de tonalidade, e a repressão, os massacres, a exploração e a discriminação passaram a ser o pão de cada dia dos angolanos". Como se isso não bastasse, "Angola, reduzida a uma penitenciária por excelência, recolhia todos os malfeitores que a Metrópole considerava altamente perigosos para a sociedade, mas que na colônia se transformassem em civilizadores" (IMBAMBA, 2010, p. 108). Na sua opinião, é impossível, na história angolana, não se abordar o papel dos degredados e os efeitos nefastos que trouxeram ao povo angolano e às culturas angolanas.

\footnotetext{
${ }^{14}$ Muitos outros autores, pensadores, linguistas e acadêmicos angolanos estão a surgir no campo da interdisciplinaridade, da interculturalidade e multiculturalidade com contribuições ricas e inéditas, como Márcio Undolo, António Filipe Augusto, Mona Mpanzu, Ima Panzo, Afonso João Miguel, Paulo Adriano Soma, Agnaldo Jaka Tchivinda, António Quino, Chionga Bali Nunes, entre outros. Sugerimos a consulta/leitura da tese de doutoramento de Filipe Abraão do Couto - intitulada A relação entre pensamento português e pensamento angolano: que lusofonia? - , do Instituto de Letras e Ciências Humanas da Universidade do Minho.

${ }^{15}$ Muntu não significa só o "homem". O muntu certamente possui um corpo visível, mas o corpo não é o muntu. O muntu assemelha-se mais com o que os ocidentais chamam de "pessoa", e não tanto como "o homem". Muntu significa, assim, "força vital, empossado com inteligência e vontade". Muntu é singular, em oposição a Bantu, que é plural. Recorreu-se à definição desta palavra na obra de um dos pioneiros da filosofia africana: Placide Tempels (cf. TEMPELS, 1959, p. 37).
} 
Também António Filipe Augusto, linguista angolano, considera que é impossível negar a importância do lusotropicalismo enquanto fenômeno histórico que está relacionado com a lusofonia e a opressão exercida sobre os angolanos durante séculos. Negar a influência do lusotropicalismo é negar parte da história angolana, bem como a realidade atual de Angola, numa dimensão cultural e política. Neste sentido, para Augusto, não é possível fugir à ideologia lusotropicalista, não só porque representa um violentíssimo golpe na história de Angola, sobre o qual pouco se falou e discutiu, como, atualmente, ainda se estatui como um fenômeno que se perpetua violentamente com outro rosto e com outra designação (AUGUSTO, 2015).

Esta também é a posição de Muanamosi Matumona, filósofo angolano, uma vez que considera que a filosofia lusotropicalista teve e continua a ter repercussões negativas no tecido social angolano, não sendo possível divorciar a filosofia lusotropicalista no contexto da filosofia africana não só em Angola, como em todos os países africanos de expressão portuguesa. Para este pensador, o lusotropicalismo representou uma máscara para disfarçar as verdadeiras intenções dos portugueses, que partilhavam sub-repticiamente a visão de Hegel sobre África e os africanos, ${ }^{16} \mathrm{e}$ os rotulava como "coisas", objetos e não humanos, desprovidos de história e afastados da história. Longe do tratamento humanista e igualitário em relação ao outro-africano, o que continuou a prevalecer, no auge da ideologia lusotropicalista, foram os mesmos abusos de poder, o trabalhado forçado, e uma forte imposição cultural, social e linguística sobre os povos africanos.

Na sua percepção, a estratégia do lusotropicalismo consistiu "em mudar completamente todos os aspetos da vida dos africanos, incluindo a filosofia, para os afastar das suas próprias culturas e os aproximar do estilo de vida português" (MATUMONA, 2011, p. 62). Era esta a sua perspectiva de "civilização", que visava à eliminação das culturas e tradições autóctones e a erradicação do uso das línguas endógenas, para transformar o indígena à imagem do colono, por meio da língua portuguesa, da religião católica e dos costumes portugueses. No decorrer desta transformação, os africanos ainda seriam os escravos que recolheriam e transportariam os minerais, as especiarias, o marfim, que seriam, na sua opinião, os grandes objetivos das expedições portuguesas. Para este filósofo angolano, a filosofia lusotropicalista irá figurar para sempre na história de Angola, dada a sua influência pejorativa em todas as dimensões, não sendo possível eliminá-la ou omiti-la, porque isso também seria subtrair a sua própria história.

\footnotetext{
16 "Nos negros, o característico é [que] a sua consciência ainda não chegou à intuição de qualquer objetividade firme como, por exemplo, Deus, lei, na qual o homem estaria com a sua vontade e teria assim a intuição da sua essência. $\mathrm{O}$ africano, na sua unidade indiferenciada e compacta, ainda não chegou à distinção entre ele mesmo como indivíduo e a sua universalidade essencial, pelo que falta inteiramente o conhecimento de uma essência absoluta, que é um outro, superior face a si mesmo. Encontramos, pois, aqui, apenas o homem na sua imediatidade; tal é o homem em África [...] É na brutalidade e na selvajaria que vemos o homem africano, na medida em que o podemos observar; e assim permanece hoje. O negro representa o homem natural em toda a sua selvajaria e barbárie" (HEGEL, 1995, p. 177).
} 


\section{Considerações finais}

Para autores aqui citados, a que se juntam outros de igual importância e contributo para a matéria, a armadura do lusotropicalismo camuflou os verdadeiros interesses dos portugueses em Angola ao longo de quinhentos anos de colonização. Com as devidas exceções, longe de um tratamento justo e igualitário para com o outro-africano, o que prevaleceu, de uma forma geral, foi, na realidade, a crueldade física e psicológica, a humilhação da dignidade humana, o não reconhecimento das línguas e culturas angolanas, a conversão forçada do outro-africano à língua portuguesa e a apropriação ilegítima de bens materiais.

Com efeito, as observações de Bender acerca da natureza do lusotropicalismo constitui, a nosso ver, uma fonte de inspiração para uma nova geração de acadêmicos, artistas, pensadores e linguistas angolanos que não só têm enriquecido a proposta inaugural deste conceito, como também a têm conduzido para novos rumos e importantes designações que não se inscrevem divorciadas da contemporaneidade.

Desta forma, se estes "novos" autores também sublinham a forte convicção etnocêntrica da filosofia lusotropicalista que se traduziu numa missão civilizadora que os portugueses tinham de cumprir para educar e civilizar os africanos grotescos e selvagens à sua imagem e semelhança, estando muito claro que esta incumbência tinha implicado a imposição de uma cultura e de uma língua sobre todas as culturas e línguas em Angola. Também é certo afirmar que para alguns autores e acadêmicos angolanos este último fenômeno não se extinguiu com o fim da colonização em Angola, o que significa que o lusotropicalismo ainda permanece, embora acomodado com outras possíveis designações interculturais.

Neste sentido, o lusotropicalismo não só subsiste pelas várias versões da história cronológica que ainda estão por contar da colonização portuguesa em Angola, mas por tudo aquilo que ainda representa no imaginário social angolano e, mais importante, por tudo aquilo que pode representar no futuro das relações político-diplomáticas entre ambas as nações. Assim, permanecer atento aos desenvolvimentos das ideias e do conceito do lusotropicalismo em Angola, conceito que continua bem vivo nos seus autores, significa estar receptivo às questões sensíveis da interculturalidade e da interdisciplinaridade, bem como das diferentes paisagens epistemológicas.

\section{Referências}

AUGUSTO, António. África lusófona: uma identidade prótese ou mentes colonizadas, O País, 18 nov. 2015.

BENDER, Gerald. Angola sob o domínio português: mito e realidade. 3. ed. Luanda: Mayamba, 2013.

EPIFÂNIO, Renato. A via lusófona III: um novo horizonte para Portugal. Lisboa: Zéfiro, 2017. 
HEGEL, Georg. A razão na história: introdução à filosofia da história do universal. Lisboa: Edições 70, 1995.

HENRIQUES, Joana. Racismo em português: o lado esquecido do colonialismo, Público, 9 jun. de 2016. Disponível em: http://acervo.publico.pt/mundo/noticia/racismo-em-portugues-olado-esquecido-do-colonialismo-1729856. Acesso em: $11 \mathrm{dez} .2019$.

IMBAMBA, José Manuel. Uma nova cultura para mulheres e homens novos: um projeto filosófico para Angola do $3^{\circ}$ milénio à luz da filosofia de Battista Mondin. Luanda: Paulinas, 2010.

MATUMONA, Muanamosi. Filosofia africana na linha do tempo: implicações epistemológicas, pedagógicas e práticas de uma ciência moderna. Lisboa: Esfera do Caos, 2011.

SÉNGHOR, Leopold. Liberté III: négritude et civilisation de l'universel. Paris: Seiul, 1977.

TEMPELS, Placide. Bantu philosophy. Paris: Présence Africaine, 1959.

\section{Minicurrículo}

Filipe Abraão Martins do Couto é doutorado em Filosofia pela Universidade do Minho (UMinho). Possui mestrados em: Filosofia Política, pela Universidade Nova de Lisboa; Mediação Cultural e Literária e em Ensino da Filosofia, ambas pela UMinho. É licenciado em Filosofia pela Universidade de Lisboa. É professor na Faculdade de Filosofia da Universidade Nacional de Timor-Lorosa'e e investigador da UMinho. 